\title{
RESEARCHPAPER
}

\section{Efficiency of bacterial isolates from oil contaminated soil for biodegradation of diesel}

\author{
E. AYAZ AND R. GOTHALWAL \\ Department of Biotechnology and Bioinformatic Centre, Barkatullah University, BHOPAL (M.P.) INDIA \\ Email : eramayaz87@gmail.com
}

Article Info : Received : 19.07.2016; Revised : 30.08.2016; Accepted : 16.09.2016

Diesel degrading bacterial isolates Gh1 and Gh15 were isolated from crude oil contaminated soil, oil refinery of Guwahati (Assam, India) located at $26^{\circ} 11^{\prime} 0^{\prime \prime}$ North, $91^{\circ} 4^{\prime}$ ' 0 " East. Isolates showed optimized growth pattern at $35^{\circ} \mathrm{C}$, pH 6.5 and $100 \mathrm{ppm}$ diesel using as the sole carbon and energy. Optical density and gas chromatography were used as evaluation experiment to check the degradation of aromatic hydrocarbons by strain. GC-FID chromatograms indicated the highest degradation efficiency of bacterial strains for aromatic hydrocarbons after 72 hours of incubation. This native microbial isolate could be considered as a powerful approach for the in-situ bioremediation of diesel contaminated soil.

Key words : Hydrocarbons, Bacteria, Bioremediation

How to cite this paper : Ayaz, E. and Gothalwal, R. (2016).Efficiency of bacterial isolates from oil contaminated soil for biodegradation of diesel. Asian J. Bio. Sci., 11 (2) : 303-308.DOI : 10.15740/HAS/AJBS/11.2/303-308. 